[PT]

\title{
Magnetic iron-nickel sulphides in the Pliocene and Pleistocene marine marls from the Vrica section (Calabria, Italy)
}

\author{
A.J. van Velzen, M.J. Dekkers and J.D.A. Zijderveld \\ Fort Hoofddijk Paleomagnetic Laboratory, Institute of Earth Sciences, Utrecht University, Budapestlaan 17, \\ 3584 CD Utrecht, Netherlands
}

Received October 14, 1992; revision accepted January 20, 1993

\begin{abstract}
The rock magnetic properties of the late Pliocene and early Pleistocene open-marine marls from the Vrica section in Calabria (Italy) point to magnetic sulphide as the main magnetic mineral and remanence carrier. The maximum blocking temperatures, however, are between 340 and $360^{\circ} \mathrm{C}$, which is too high for stoichiometric monoclinic pyrrhotite. Magnetic concentrates of the sediment are rich in iron sulphide grains and iron-nickel sulphide grains. Microprobe observations show that most of the grains are of the order of $1 \mu \mathrm{m}$ in size and attached to iron-bearing clay flakes.

Microprobe analyses of the sulphides yield a large range of compositions, ranging from pyrite through greigite-pyrrhotite to sulphur-deficient monosulphides, and with Ni contents varying from zero to a few atom percent in the pyrite grains and from zero to as much as $35 \mathrm{~atm} \%$ in the monosulphides. The high Ni content of many of the grains is extraordinary and has not been reported before in marine sediments. Most of the compositions cannot be directly connected with a known mineral phase. The marine depositional environment of the marls imposes an authigenic origin for the sulphides, and this is supported by several observations.

The great number of sulphide grains in the magnetic concentrates suggests that at least one of the sulphide compositions must have a ferrimagnetic structure, possibly the sulphides with a metal to sulphur ratio close to that of monoclinic pyrrhotite, and between 25 and 35\% of the Fe replaced by Ni. The Ni substitution could possibly be the cause of the high blocking temperatures.
\end{abstract}

\section{Introduction}

The Vrica section (Crotone-Spartivento basin of northern Calabria, Italy) consists of openmarine marls dating from ca $2.1 \mathrm{Ma}$ to $1.55 \mathrm{Ma}$. The section has been formally designated as the Pliocene-Pleistocene boundary stratotype [1] and has consequently been intensively studied [e.g. 2-7]. Most recent paleomagnetic results from the Vrica section contributed to a detailed magnetostratigraphy for the late Pliocene to early Pleistocene and the absolute age for the $\mathrm{P} / \mathrm{P}$ boundary [8]. The groups of sapropelitic layers that are found throughout the section in the otherwise homogeneous marls are interpreted as interference patterns related to the Earth's orbital cycles $[9,10]$ and provide an astronomically calibrated polarity time scale for the time interval represented by the section.

During the recent magnetostratigraphic study [8] much attention was paid to the interpretation of the thermal demagnetization diagrams. For the present study rock magnetic measurements were performed and magnetic concentrates were made in order to improve our understanding of the demagnetization process. This paper reports the results of microprobe analyses of magnetic concentrates.

\section{Sampling sites}

Concentrates were made of two samples (VBA 1 and VBA 6) taken from subsection Vrica $\mathrm{B}, 2.5$ m below sapropel $c$ and $0.5 \mathrm{~m}$ below sapropel $h$ 


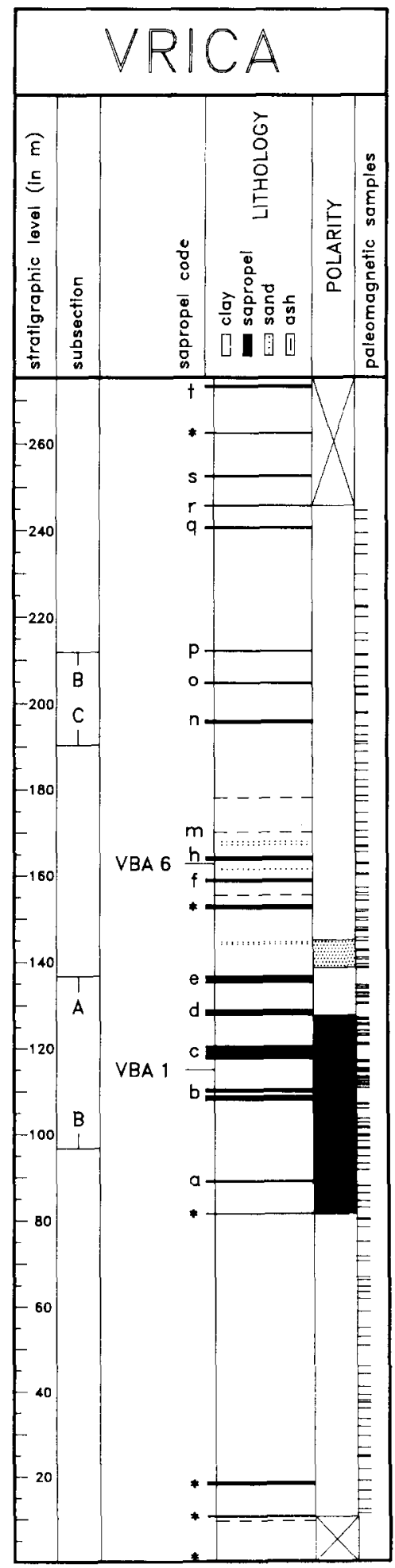

respectively (sapropel labelling by Selli et al. [3], see Fig. 1). The average accumulation rate of subsection Vrica B is $30 \mathrm{~cm} / \mathrm{ky}$ [8]. Between sapropels $b$ and $c$ and between $f$ and $h$ the sedimentation rate was 14 and $23 \mathrm{~cm} / \mathrm{ky}$ respectively on the basis of the astronomical age of the individual sapropels [10]. The sedimentation depth was about $500 \mathrm{~m}$. Conditions were oxygenpoor or anoxic during deposition of the sapropelitic layers, but at other times they were oxygenated.

The carbonate content of the marls ranges from $13 \%$ (in the sapropels) to $25 \%[11,12]$. In the non-sapropel sediment the organic carbon content is between 0.4 and $0.8 \%$ [12]. The clay minerals in the Vrica section are mainly smectite (ca. 55\%), illite (20\%), chlorite (15\%) and kaolinite $(10 \%)[12,13]$.

\section{Natural remanent magnetization}

The intensities of the natural remanent magnetization (NRM) in the Vrica section vary considerably [8]. In the lower part of subsection Vrica B up to sapropel $c$ relatively high intensities are found $(0.5-3 \mathrm{~mA} / \mathrm{m})$. Progressive thermal demagnetization removes a characteristic component with a normal polarity between 200 and $300^{\circ} \mathrm{C}$, after demagnetizing a viscous laboratory component at $100^{\circ} \mathrm{C}$ and a small secondary component with a slightly different direction at about $200^{\circ} \mathrm{C}$ (Fig. 2A). The upper limit of the demagnetization temperatures remains obscure, however, due to the spurious behaviour of the remanence starting around $340^{\circ} \mathrm{C}$. The increase of the bulk susceptibility of the samples, which starts at the same temperature, indicates the formation of new magnetic minerals in this temperature range (Fig. 2C).

Above sapropel $c$ NRM intensities drop to $0.1-0.2 \mathrm{~mA} / \mathrm{m}$. Due to the low intensities and consequently relatively large secondary remanences it is often more difficult to determine

Fig. 1. Vrica composite section. Samples VBA 1 and VBA 6 were taken from subsection Vrica $B$ at the stratigraphic levels $114 \mathrm{~m}$ and $162 \mathrm{~m}$, respectively. Magnetostratigraphic results in [8]. Normal polarities are indicated in black, reversed polarities in white. 
characteristic directions in this interval (Fig. 2B). Half way between sapropels $e$ and $f$ NRM intensities start to increase again to values between 0.1 and $0.5 \mathrm{~mA} / \mathrm{m}$. Thermal demagnetization diagrams are similar to those in the lower part of the subsection, only here the characteristic component removed between 200 and 300 or $340^{\circ} \mathrm{C}$ has a reversed polarity. Above $340^{\circ} \mathrm{C}$ again the formation of new magnetic minerals prevents further interpretation of the demagnetization results. Alternating field demagnetization would avoid thermal alterations, but alternating fields higher than $40 \mathrm{mT}$ create new remanences that disturb the demagnetization process.

The overall trend in the NRM intensities of the section is distinct, but on a small scale the sediment is quite inhomogeneous with respect to the magnetic properties. Samples taken next to each other can have very different NRM intensities and demagnetization behaviour.

\section{Rock magnetic properties of the sediment}

The rock magnetic properties of the sediment indicate that the dominant magnetic mineral might be an iron sulphide. Isothermal remanent magnetization (IRM) acquired in fields up to $2 \mathrm{~T}$ varies between 0.1 and $0.8 \mathrm{~A} / \mathrm{m}$. Coercivities are generally lower than $0.3 \mathrm{~T}$, and this is confirmed by the alternating field demagnetization of the
IRM (Fig. 3A and B). Remanent coercivities $\left(H_{\mathrm{cr}}\right)$ are between $45 \mathrm{mT}$ for the low-intensity samples and $80 \mathrm{mT}$ for the high-intensity samples. Sites VBA 1 and VBA 6 both have relatively high intensities (Table 1). Their coercivities are substantially higher than typical magnetite coercivities [e.g. [14]) and compare well with coercivities of pyrrhotite grains in the pseudo-single domain size range $[15,16]$. Thermal demagnetization of IRM (Fig. 3C) shows that a large part of the remanence has maximum demagnetization temperatures lower than $360^{\circ} \mathrm{C}$, comparable to those of the NRM. A smaller part of the remanence has maximum demagnetization temperatures well above $500^{\circ} \mathrm{C}$. The linear decay of the latter remanence points to very fine magnetite grains in the size range between superparamagnetic and stable single domain grain sizes [cf. 17]. It is not possible to establish whether a small part of the NRM also has these high blocking temperatures. The NRM intensities are only $0.1 \%$ of the IRM intensities and the NRM demagnetizations are disturbed by the thermal alterations above $340^{\circ} \mathrm{C}$.

The coercivities and the maximum demagnetization temperatures are close to those of monoclinic pyrrhotite, except that the maximum demagnetization temperatures are some $20-40^{\circ} \mathrm{C}$ higher than the Curie temperature of monoclinic pyrrhotite, which is generally reported as being between 305 and $325^{\circ} \mathrm{C}$ [e.g. 18-21]. However,
A

B

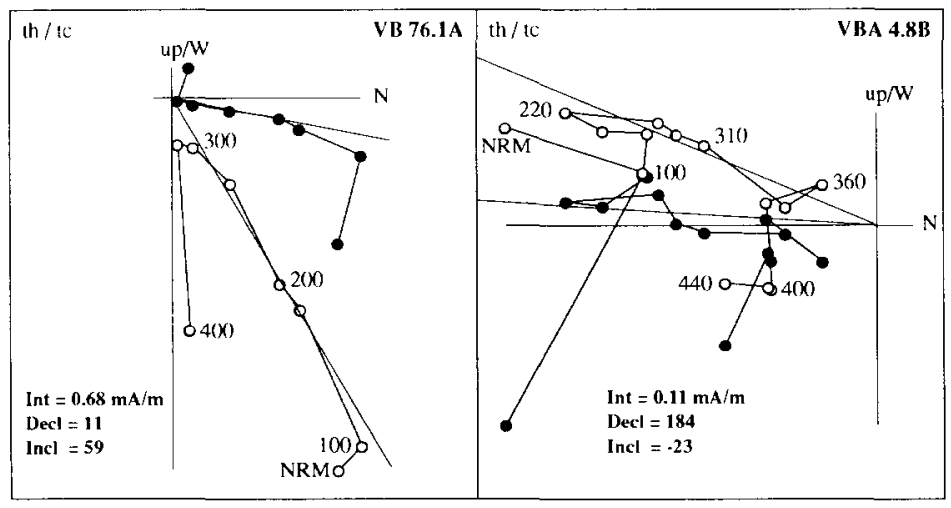

C

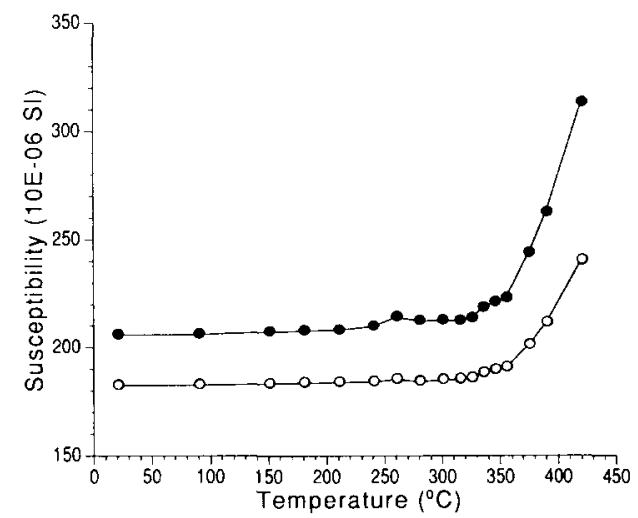

Fig. 2. (A) Stepwise thermal demagnetization of a sample with a relatively high NRM intensity from the lower part of subsection Vrica B. Closed symbols and open symbols are horizontal and vertical projection respectively. Temperatures in degrees centigrade. Int is NRM intensity at $200^{\circ} \mathrm{C}$. Decl and Incl are calculated as the best fit for the vector removed between ca. 200 and $300^{\circ} \mathrm{C}$. (B) The same for a sample from the part of the section characterized by lower NRM intensities. (C) Changes in initial susceptibility occurring during the thermal demagnetization. High-intensity sample shown by closed symbols; low-intensity sample shown by open symbols. 
higher maximum blocking temperatures (up to $350^{\circ} \mathrm{C}$ ) were found in fine-grained pyrrhotites by Rochette et al. [22]. The spurious magnetizations
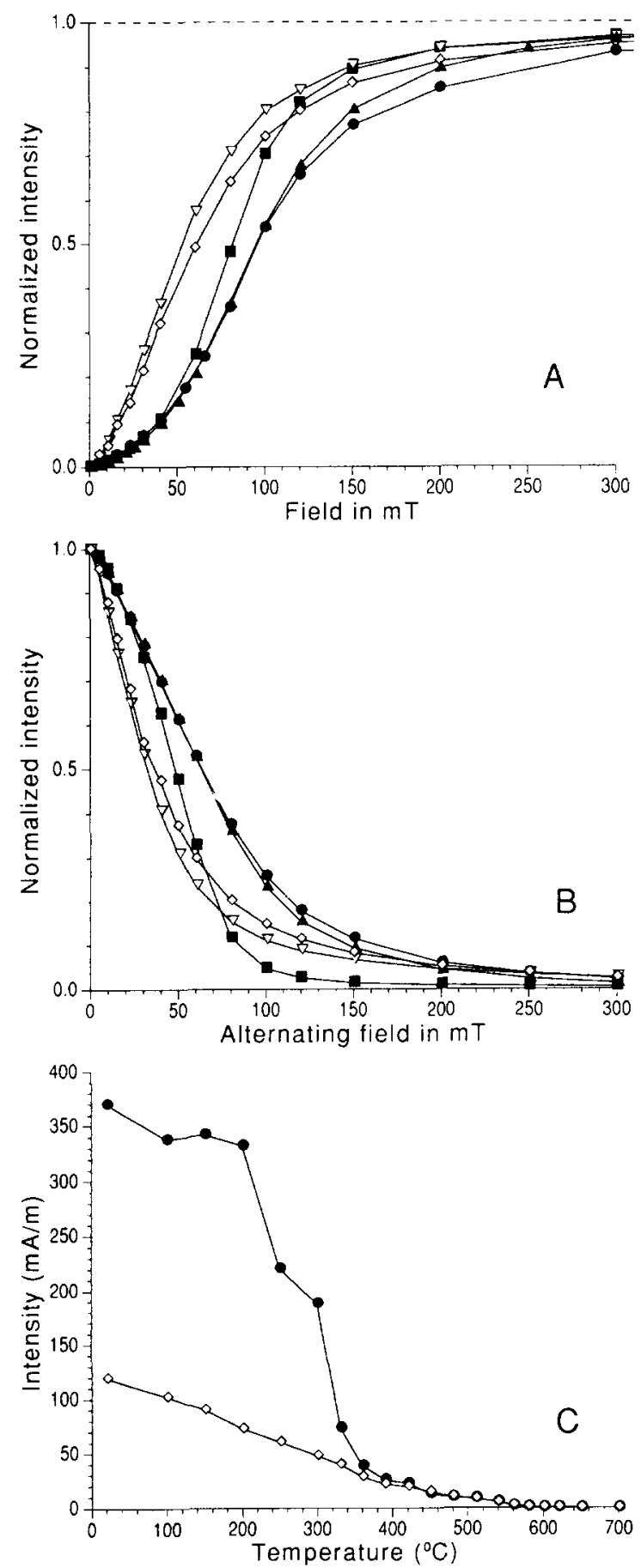

TABLE 1

Rock magnetic properties at the sampling sites

\begin{tabular}{lll}
\hline & VBA 1 & VBA 6 \\
\hline Stratigraphic level & $114 \mathrm{~m}$ & $162 \mathrm{~m}$ \\
Polarity & normal & reversed \\
NRM intensities & $0.15-2.5 \mathrm{~mA} / \mathrm{m}$ & $0.05-0.37 \mathrm{~mA} / \mathrm{m}$ \\
Average & $0.5 \mathrm{~mA} / \mathrm{m}$ & $0.2 \mathrm{~mA} / \mathrm{m}$ \\
IRM (2T) & $380-680 \mathrm{~mA} / \mathrm{m}$ & $460-760 \mathrm{~mA} / \mathrm{m}$ \\
$H_{\text {cr }}$ & $80-81 \mathrm{mT}$ & $73-78 \mathrm{mT}$ \\
MDF of IRM (2T) $*$ & $62 \mathrm{mT}$ &
\end{tabular}

* Median destructive fields of stationary alternating field demagnetization in three orthogonal directions.

that occur during AF demagnetization of the NRM are also similar to the behaviour found in pyrrhotites [23,24].

Greigite $\left(\mathrm{Fe}_{3} \mathrm{~S}_{4}\right)$ is also known to be a strongly magnetic mineral occurring in reducing sedimentary environments [e.g. 25-27, and references therein]. The mireral becomes thermally unstable at about $300^{\circ} \mathrm{C}$, however, which is not compatible with the high maximum blocking temperatures observed in the marls in this study. Moreover, coercivities reported for greigite are generally lower than those of pyrrhotite. Like pyrrhotite, greigite exhibits spurious behaviour during AF demagnetization [28].

Pyrrhotite and greigite cannot explain the combination of high blocking temperatures and high coercivities. However, the observed rock magnetic properties do not exclude these two pure iron sulphides as contributors to the remanence.

\section{Magnetic concentrates}

For further study of the magnetic minerals in the sediment magnetic separation was performed. A suspension of $400 \mathrm{~g}$ of sediment in 21 of demineralized water was slowly passed through a

Fig. 3. (A) IRM acquisition of samples with high-intensity NRM (closed symbols) and low-intensity NRM (open symbols). Normalized at $2 \mathrm{~T}$. The IRM of the high-intensity samples is about four times the IRM of the weak samples. (B). Alternating field demagnetization of the normalized IRM (2T) of the same samples. Demagnetization was stationary in three orthogonal directions. Rock magnetic data for samples VBA 1 and VBA 6 in Table 1. (C). Stepwise thermal demagnetization of IRM (2T) 
glass tube between the poles of a Frantz isodynamic separator operating at a high current (1.5 A). Some ascorbic acid was added to the suspension in order to create slightly reducing conditions and prevent possible oxidation of mineral phases. Every few hours the circulation was stopped and the mineral grains attracted by the magnet were washed from the tube. They were stored under reducing conditions in demineralized water with some ascorbic acid. This first magnetic concentrate still consisted mainly of clay minerals, and it was subjected to a second concentration step to separate the strongly magnetic fraction from the less magnetic part. The suspension was again passed between the poles of the isodynamic separator, first operating at a low current $(0.25 \mathrm{~A})$, to obtain only highly magnetic minerals (yield ca $0.03 \mathrm{~g}$ ), and then at a high current to extract the remaining magnetic minerals (yield ca. $3 \mathrm{~g}$ ). The two concentrate fractions still contained a considerable amount of clay minerals.
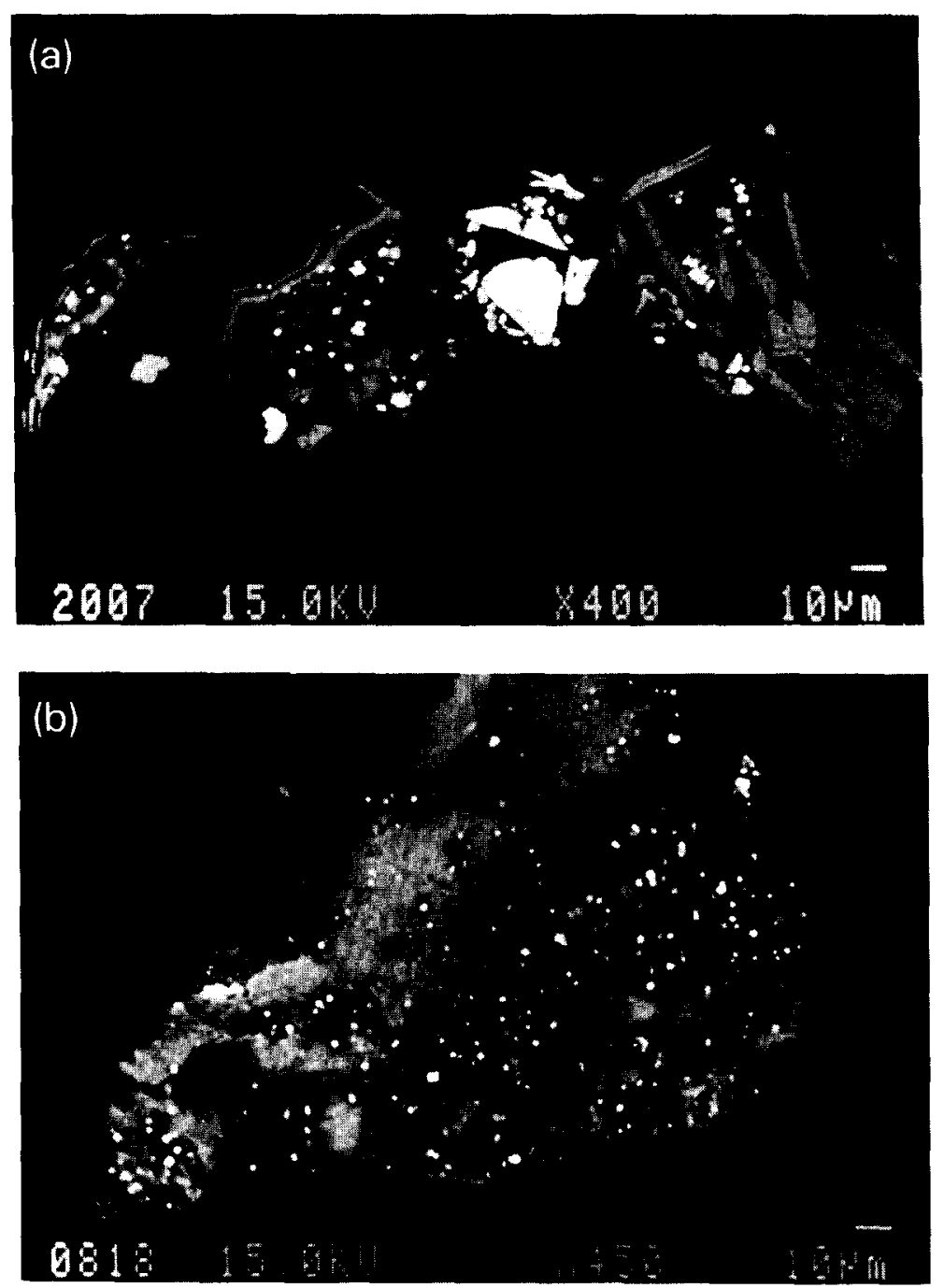

Fig. 4. Microprobe back scatter images of grains separated in low magnetic fields (VBA 6). Sulphide grains appear bright in the image. (a) A collection of different clay flakes, iron-titanium oxides (large white pieces) and iron-nickel sulphides (the small white grains on and between the flakes) with ca. $15 \mathrm{~atm} \% \mathrm{Ni}$. (b) Many small sulphide grains on an iron-bearing clay flake: mainly pyrite grains, sometimes with a trace of $\mathrm{Ni}(0.2 \mathrm{~atm} \%)$ and some monosulphide grains with ca. $45 \mathrm{~atm} \% \mathrm{~S}$ and $4-6$ atm $\% \mathrm{Ni}$. 

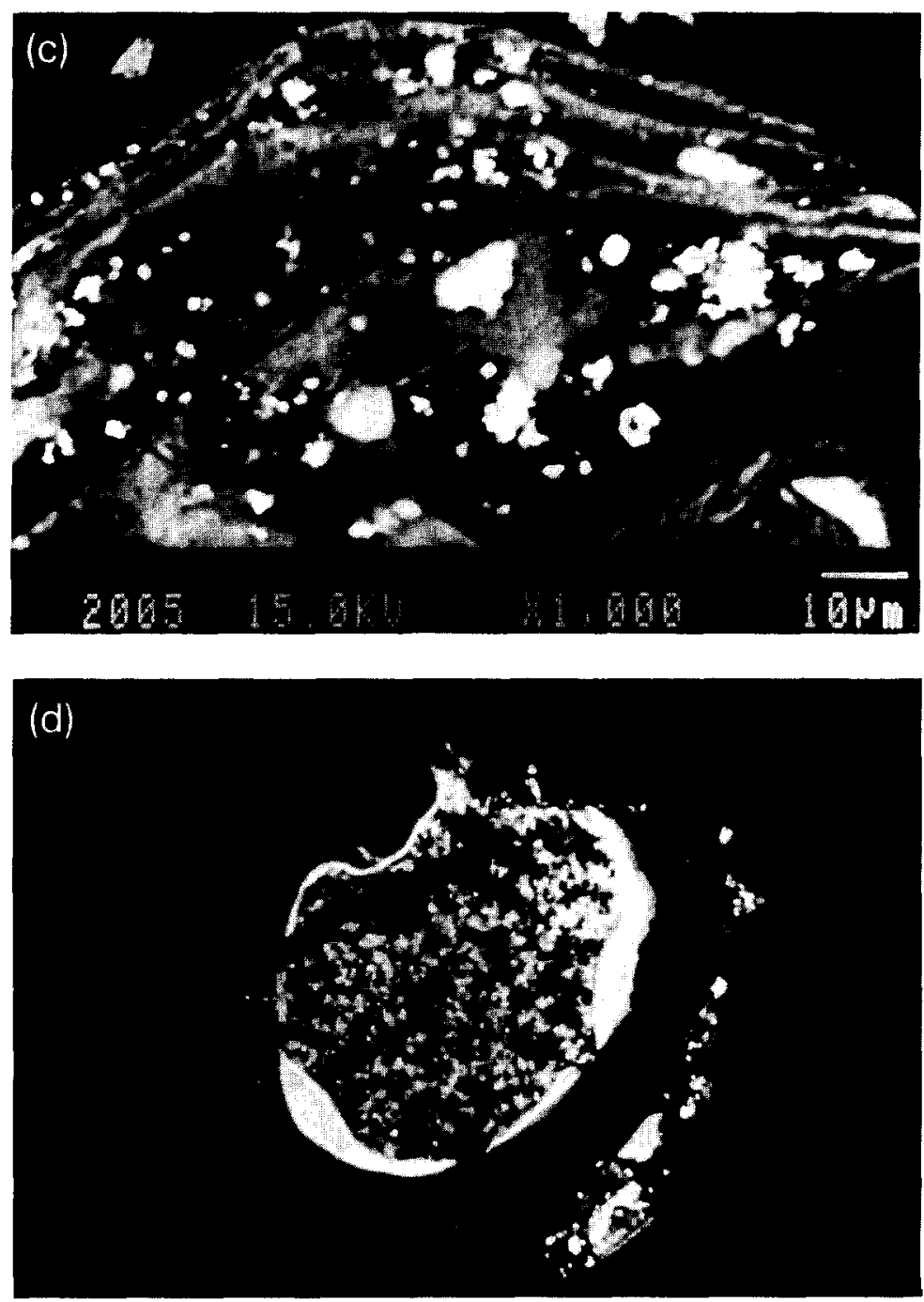

Fig. 4. (c) Iron-bearing clay flake with sulphide grains: pyrite (without $\mathrm{Ni}$ ) and monosulphide grains ( 42 atm $\%<\mathrm{S}<47$ atm\%) with between 4.5 and 17 atm\% Ni. (d) Carbonate shell with sulphides that approximate monosulphides, containing $\mathrm{Fe}, \mathrm{Ni}$ and $\mathrm{Zn}$. The $\mathrm{Zn}$ content of the sulphide increases towards the middle of the cavity (see Table 3). The width of the shell is ca $140 \mu \mathrm{m}$ (magnification $350 \times$ ).

Polished thin sections of the concentrates were prepared for microprobe analysis (EDA) and electron microscope observation to determine the composition and appearance of the magnetic particles.

\section{Microprobe observations}

Back scatter images of the polished thin sections confirm that all concentrates still contain a large number of clay flakes. In low-field concentrates of VBA 6 many of the clay flakes have small grains attached to them; these are the bright areas in the images (Fig. 4). These bright grains are sulphides of various compositions. As expected, sulphur and iron form the main constituents of these grains, although many of them also contain a large amount of nickel.

Microprobe analysis of the clay flakes on which sulphide grains were observed reveals that these 


\section{TABLE 2}

Some representative microprobe analyses of clay minerals that have sulphide grains attached to them, of some $\mathrm{Fe}-\mathrm{Cr}$ oxides, and of some $\mathrm{Fe}-\mathrm{Ti}$ oxides. The values are given as atom percentages normalized to $\mathrm{Si}$ (for the clay flakes with sulphides) and $\mathrm{Fe}$ (for the $\mathrm{Fe}-\mathrm{Cr}$ and $\mathrm{Fe}-\mathrm{Ti}$ oxides). The clay flakes come from magnetic concentrates that were separated with low and with high magnetic fields. The $\mathrm{Fe}-\mathrm{Cr}$ oxides come from the low-field concentrate of VBA 6

\begin{tabular}{|c|c|c|c|c|c|c|c|c|}
\hline & $\mathrm{Si}$ & $\mathrm{Al}$ & $\mathrm{Mg}$ & $\mathrm{Fe}$ & $\mathrm{K}$ & $\mathrm{Ca}$ & Other elements & \\
\hline \multirow{5}{*}{$\begin{array}{l}\text { Clay flakes with } \\
\text { sulphides }\end{array}$} & 1 & 1.07 & 0.49 & 0.99 & 0.02 & 0.00 & & VBA 1 low field \\
\hline & 1 & 0.75 & 0.81 & 0.51 & 0.02 & 0.01 & $\mathrm{Na}, \mathrm{Ti}, \mathrm{S}$ & VBA 1 high field \\
\hline & 1 & 0.63 & 0.34 & 0.49 & 0.21 & 0.01 & $\mathrm{Na}, \mathrm{Ti}, \mathrm{S}$ & VBA 6 low field \\
\hline & 1 & 0.60 & 0.21 & 0.35 & 0.13 & 0.06 & $\mathrm{Na}, \mathrm{Ti}, \mathrm{S}$ & VBA 6 high field \\
\hline & $\mathrm{Fe}$ & $\mathrm{Cr}$ & $\mathrm{Ni}$ & $\mathrm{Mn}$ & $\overline{\mathrm{Mg}}$ & & & \\
\hline \multirow[t]{4}{*}{$\mathrm{Fe}-\mathrm{Cr}$ oxides } & 1 & 0.25 & 0.12 & 0.02 & & & $\mathrm{Si}, \mathrm{Al}$ & \\
\hline & 1 & 0.16 & & 0.02 & & & Ni, Mg, Ti, Si, Al & \\
\hline & 1 & 0.21 & & 0.01 & 0.03 & & $\mathrm{Ti}, \mathrm{Zn}, \mathrm{Si}, \mathrm{Al}$ & \\
\hline & $\overline{\mathrm{Fe}}$ & $\mathrm{Ti}$ & & $\mathrm{Mn}$ & $\mathrm{Mg}$ & & & \\
\hline \multirow[t]{3}{*}{ Fe-Ti oxides } & 1 & 1.02 & & 0.02 & 0.07 & $\mathrm{Si}$ & & \\
\hline & 1 & 1.13 & & 0.08 & 0.01 & $\mathrm{Si}$ & & \\
\hline & 1 & 0.5 & & 0.01 & 0.05 & $\mathrm{Al}$ & & \\
\hline
\end{tabular}

clay flakes contain iron (Table 2). Apart from the clay minerals and sulphides, a few grains containing iron and titanium were found occurring in sizes ranging from 1 to $50 \mu \mathrm{m}$. These grains often have sharp edges and $\mathrm{Fe}$ : $\mathrm{Ti}$ ratios close to unity, indicating that they are grains of ilmenite, which is paramagnetic at room temperature [e.g. 29]. $\mathrm{Fe}-\mathrm{Ti}$ grains with other ratios were seldom found. In the VBA 6 low-field concentrates grains with $\mathrm{Fe}$ and $\mathrm{Cr}$ are also present. These grains usually contain as least twice as much $\mathrm{Fe}$ as $\mathrm{Cr}$, and in some instances they also contained considerable amounts of $\mathrm{Ni}$ and traces of other metals (Table 2 ). These grains are supposedly paramagnetic too.

The abundance of the sulphides and the absence of other magnetic minerals in the magnetic concentrates indicates that these sulphide grains contribute to an important part of the remanent magnetic signal in the marls. Attention was therefore focussed on these iron-nickel sulphides. Most sulphide grains are attached to clay flakes and have a uniform appearance. The majority of the grains are smaller than $1.5 \mu \mathrm{m}$ and seem to be spherical (although for the smallest grains it is difficult to assess the exact shape, because they are close to the detection limit of the microprobe). The measurement of the exact composition of the sulphide grains with the microprobe was complicated by the small size of most of the grains ( $<1.5 \mu \mathrm{m}$, a size that is comparable to the spot size of the electron beam (ca $1 \mu \mathrm{m}$ )). In addition, the sulphide grains are possibly thin, so that part of the background (generally a clay flake) may be analyzed together with the sulphide grain. These conditions result in biased compositions for the suphides, especially whith respect to Fe. Therefore, the clay flake background was measured separately and the composition of the sulphide grains was corrected for iron from the background, assuming that all $\mathrm{Si}$ and $\mathrm{Al}$ measured is actually derived from the background. After correction the atom percentages are considered to be fairly accurate. Depending on the magnitude and the estimated accuracy of the correction the results are divided into well-determined (with estimated errors less than $2 \mathrm{~atm} \%$ $\mathrm{S}$ and $2 \% \mathrm{Ni}$ ) and somewhat less well determined (errors < 4\%) compositions.

Most microprobe analyses were performed on sulphide grains in the low- and high-field concentrates of VBA 6 and on some in the concentrates of VBA 1. Some of the very dispersed sulphides in polished thin sections of the original sediment were also analyzed. The sulphur percentage in the grains varies over a large range (Fig. 5), from compositions close to pyrite, via pyrrhotite, to sulphur contents close to that of pentlandite. The percentage of nickel replacing the iron in the 
sulphides is not restricted to a few percent only, and $\mathrm{Ni}$ concentrations of up to $35 \%$ are measured.

The sulphide compositions can be roughly divided into four groups: (1) a pyrite group with $60-70 \% \mathrm{~S}$ and occasionally a few percent $\mathrm{Ni},(2)$ a greigite-pyrrhotite group with $52-60 \% \mathrm{~S}$ and generally high $\mathrm{Ni}$ content $(20-35 \%$ of the total metal content), (3) a large group with $\mathrm{S}$ content between 43 and $52 \%$ and $\mathrm{Ni}$ percentages from zero to 32 , and (4) a highly sulphur deficient group with less than $43 \% \mathrm{~S}$ and $\mathrm{Ni}$ between 5 and $15 \%$ of the total metal content.

The compositions of sulphide grains on a single clay flake are not always the same. Iron sulphides with and without $\mathrm{Ni}$ occur on the same flake. Also, pyrite-like compositions and monosulphide compositions may occur together on the same flake.

In one case, on the inside of a carbonate shell (Fig. 4d), zinc was found to be a major constituent of the iron-nickel sulphides. The sulphur content of separate grains varies only between

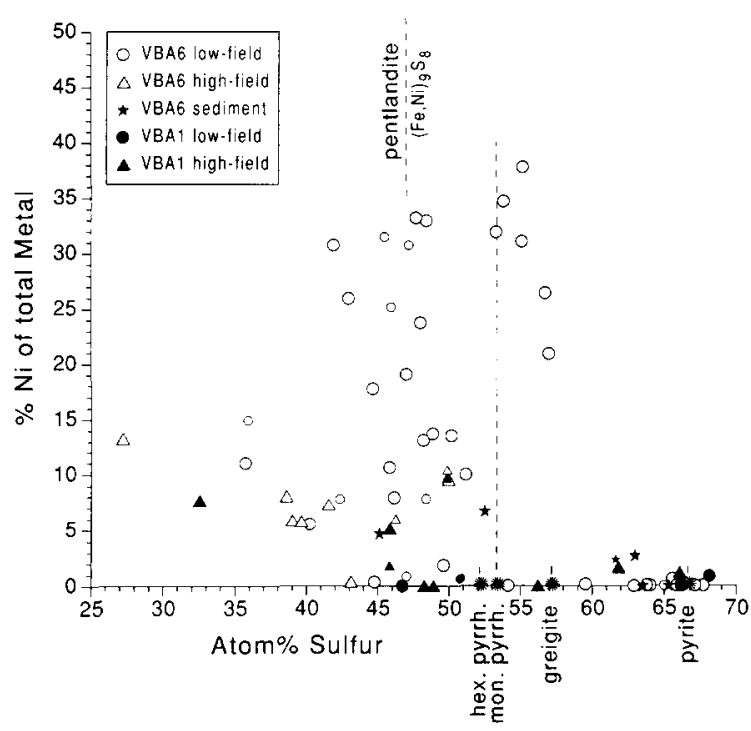

Fig. 5. Microprobe analyses (EDA) of sulphide grains from VBA 6 (low- and high-field magnetic concentrates and a sediment thin section) and VBA 1 (magnetic concentrates). Larger symbols for the most accurate measurements (see text). The microprobe was calibrated for $\mathrm{Fe}, \mathrm{Ni}$ and $\mathrm{S}$ with standards of pure iron, pure nickel and pyrite. Asterisks denote the position of four iron sulphides in the diagram. The $\mathrm{Ni}$ content in natural pentlandites varies between 35 and $66 \%$ of the total metal.

\section{TABLE 3}

Microprobe analyses of sulphides inside carbonate shell. The microprobe was calibrated for $\mathrm{Fe}, \mathrm{Ni}$ and $\mathrm{Zn}$ with standards of pure $\mathrm{Fe}, \mathrm{Ni}$ and $\mathrm{Zn}$ and for $\mathrm{S}$ with pyrite

\begin{tabular}{|c|c|c|c|c|}
\hline Position & atm\% S & $\mathrm{atm} \% \mathrm{Fe}$ & $\operatorname{atm} \% \mathrm{Ni}$ & atm\% $\mathrm{Zn}$ \\
\hline In carbonate & 44.7 & 55.0 & 0.2 & 1.0 \\
\hline Edge of carbonate & 49.6 & 49.4 & 0.9 & 0.6 \\
\hline Edge of carbonate & 50.7 & 43.7 & 4.8 & 0.6 \\
\hline In middle & 48.1 & 11.3 & 0.1 & 40.4 \\
\hline In middle & 46.2 & 17.2 & 0.1 & 36.4 \\
\hline
\end{tabular}

46.2 and 50.7 atm\%, placing them in the third group of sulphide compositions. The metal content, however, varies considerably. On the inside edge of the shell the sulphides contain a variable amount of $\mathrm{Ni}(0.2-4.8 \%$, see Table 3$)$ and $\mathrm{Zn}$. Zinc becomes more important nearer the middle of the cavity, where it is a major constituent (up to $40 \mathrm{~atm} \%$ of the sulphide). This increase in $\mathrm{Zn}$ content towards the middle of the cavity may reflect time-dependent availability of the metal ions [30]. This is a typical example of authigenic sulphide formation related with the presence of organic material [cf. 31,32]. Black spots found throughout the sediment probably represent similar concentrations of sulphides, some of which may be magnetic. This would explain why the sediment is very inhomogeneous with respect to the remanent intensities (cf. Table 1).

\section{Comparison with known sulphides}

The wide range of sulphide compositions makes it difficult to determine which sulphide or sulphides are the remanence carriers. Most of the sulphide compositions of the grains found in the sediment are not compatible with any known mineral. In particular, the high $\mathrm{Ni}$ content of many of the grains is very distinctive compared to any natural sulphide reported hitherto. Most sulphides of the first group (60-70\% S) have compositions close to pyrite $\left(\mathrm{FeS}_{2}\right)$, with occasionally some $\mathrm{Ni}$ (up to $2 \%$ ). The grains containing $\mathrm{Ni}$ could be a member of the bravoite $(\mathrm{Fe}, \mathrm{Ni}) \mathrm{S}_{2}$ solid solution series. Bravoite has a highly variable Ni content and has been synthesized at low temperatures [33]. Unlike the sulphides in the sediment, bravoite is metastable. It is difficult to 
imagine that the observed low $\mathrm{Ni}$ content will change the diamagnetic properties of the pyrite.

In the second group a number of grains have sulphur contents between greigite $(57.1 \mathrm{~atm} \% \mathrm{~S})$ and pyrrhotite $(53.3 \mathrm{~atm} \% \mathrm{~S})$ and very high $\mathrm{Ni}$ contents (20-35\%). Smythite, with a composition of $(\mathrm{Fe}, \mathrm{Ni})_{9} \mathrm{~S}_{11}$, is also in this range $(55 \mathrm{~atm} \% \mathrm{~S})$. This mineral is often observed in combination with pyrrhotite [34] and greigite mineralizations [31]. Smythite is magnetic [20,34], but it has a very limited thermal stability $\left(<75^{\circ} \mathrm{C}[35]\right)$, and it would not therefore survive our thermal demagnetization at higher temperatures. Also, the smythites reported have only a very low $\mathrm{Ni}$ content.

The third group is sulphur deficient, with $\mathrm{Ni}$ ranging from 0 to $32 \%$. The sulphur content is close to that of pentlandite $\left((\mathrm{Fe}, \mathrm{Ni})_{9} \mathrm{~S}_{8}, 47.4\right.$ atm\% S), but the $\mathrm{Ni}$ content is lower than in naturally occurring pentlandites $(35-66 \%$ [20]). The measured chemical composition is not consistent with any known mineral. However, a synthetic iron sulphide $\left(\mathrm{Fe}_{9} \mathrm{~S}_{8}\right)$ with the cubic pentlandite structure has been prepared by the flashevaporation technique of vacuum deposition [36]. No properties of this $\mathrm{Fe}_{9} \mathrm{~S}_{8}$ are known. One could speculate on having found the natural analogue of this synthetic mineral, an extension of the pentlandite compositonal range to more $\mathrm{Ni}$ poor, and even Ni-free, compositions. Since both $\mathrm{Fe}_{9} \mathrm{~S}_{8}$ and pentlandite have the same cubic pentlandite structure, it is not unlikely that all compositions ranging from 0 to $30 \% \mathrm{Ni}$ have the same cubic structure. The ordering of the $\mathrm{Ni}$ ions in the lattice could then determine whether the sulphide has ferrimagnetic properties. Pentlandite itself is paramagnetic and is associated with magmatic ore deposits, in which it often occurs intergrown with pyrrhotite. Pentlandite/ pyrrhotite intergrowths are formed through exsolution from the ( $\mathrm{Fe}, \mathrm{Ni}) \mathrm{S}$ solid solution series, the series being complete at high temperatures. This mode of occurrence does not imply that the present Ni-poor 'pentlandite' observed in our marls is detrital: apart from the fact that pentlandite weathers easily, the deviating $\mathrm{Ni}$ content of the sulphide grains also argues against a detrital origin.

Many sulphides of this third group also have a sulphur content close to that of mackinawite
$\left(\mathrm{Fe}_{1+x} \mathrm{~S}\right.$, with $0.04<x<0.07$, i.e. $48.3-49.0 \mathrm{~atm} \%$ S) or troilite (FeS). Mackinawite is a metastable low-temperature mineral that can incorporate a large amount of $\mathrm{Ni}$ (and $\mathrm{Co}$ ) in its structure. Vaughan [37] found up to $18.7 \mathrm{wt} \% \mathrm{Ni}$ in mackinawite in basic rocks and Clark [38] up to $8 \% \mathrm{Ni}$. Mössbauer studies have yielded conflicting results on whether mackinawite possesses a magnetic structure $[39,40]$. Troilite $(\mathrm{FeS})$ is antiferromagnetic, but terrestrial troilite is extremely rare, occurring only in meteorites. Possible Ni substitution is not known.

The fourth group of grains is even more sulphur deficient than the third. Grains from this fourth group have a limited but not unimportant Ni content. A mineral with a similar metal to sulphur ratio is heazlewoodite $\left(\mathrm{Ni}_{3} \mathrm{~S}_{2}\right)$, which is paramagnetic [20].

Although the microprobe analyses are accurate, there are two complicating factors that must be taken into consideration. One is the possibility that the sulphide grains actually consist of two (or more) intimately intergrown phases. Because the grain sizes are of the order of $1 \mu \mathrm{m}$, intergrowths would not be visible under the microprobe. The analyses would then yield average values for sulphur, iron and nickel, between the true compositions of the two distinct phases. No indications exist for such intergrowths, however, and the high $\mathrm{Ni}$ content of the sulphides would still remain unexplained. Another complicating factor might be a possible oxidation of the sulphides during concentration and preparation for the microprobe. The concentration procedure was performed under reducing conditions, so oxidation should be inhibited, but the sulphides nevertheless remain vulnerable to this process. Indeed, one thin section of a concentrate was visibly oxidized after polishing and had to be prepared a second time. Thus, a slight degree of oxidation cannot be ruled out. Supposing that the $\mathrm{Ni} / \mathrm{Fe}$ ratio were not affected by superficial oxidation, the analyses would yield a slightly diminished $S$ content. The real S percentage would be slightly higher. It is therefore possible that the four analyses with a very low $\mathrm{S}$ content are due to more severe oxidation. In general, however, considering the consistency of the analyses between concentrates, discrepancies are not expected to be very large. 


\section{Origin of the iron-nickel sulphides}

Iron sulphides are very common in marine sediments. Authigenic pyrite formation through bacterially mediated sulphate reduction occurs wherever reducing conditions are established and iron and sulphate are available. Pyrite is the final product in a chain of reactions starting with the formation of so-called amorphous FeS. Subsequent to this $\mathrm{FeS}$ phase, mackinawite, greigite and finally pyrite are formed. Amorphous FeS, mackinawite and greigite are usually referred to as Fe-monosulphides. These intermediate monosulphides are in principle metastable [e.g. 41-43], but they may be preserved in the sediment when sulphate from the porewater is depleted and reducing conditions continue to exist. Mossmann et al. [43] conclude that polysulphides are necessary for the reaction of monosulphides to pyrite. Hence, monosulphides may be preserved if formation of polysulphides is inhibited. The observation of pyrrhotite in sediments is, however, rather enigmatic from the sulphate reduction point of view, and only Sweeny and Kaplan [44] mention hexagonal pyrrhotite as part of the sulphate reduction reaction chain.

In contrast to the omnipresence of iron sulphides, the presence of nickel-bearing sulphides in marine sediments is rarely reported. Luther et al. [45] found up to $4 \mathrm{wt} \% \mathrm{Ni}$ in pyrite framboids in recent estuarine sediments in Newark Bay, New Jersey. They also found $\mathrm{Zn}$ and $\mathrm{Mn}$ sulphides in the sediment. Authigenic greigitesmythite mineralizations with on average $0.2 \mathrm{wt} \%$ $\mathrm{Ni}$ have been reported from Middle Miocene claystones in Bohemia [26,28,31]. Whenever iron-nickel sulphides in a sedimentary environment are reported, the contribution of $\mathrm{Ni}$ is restricted to a few percent. It is therefore remarkable that the Ni content of sulphide grains in the Plio-Pleistocene marine sediments from the Vrica section is much higher, even more so because the abundant presence of sulphide grains in the magnetic concentrates demonstrates that at least one, and possibly several, of the sulphide compositions is strongly magnetic.

The iron and iron-nickel sulphides in the Vrica sediment have an authigenic origin. Detrital sulphides are very unlikely to occur in a marine environment. Sulphides such as pyrite, and espe- cially pyrrhotite and greigite, are readily oxidized under the oxic conditions to which they are subjected during transport [e.g. 46]. An iron-nickel sulphide such as pentlandite also weathers under atmospheric conditions.

The relatively high sedimentation rate and input of organic material created a reducing environment once the sediment was sealed from the oxygenated bottom waters [e.g. 42], setting the stage for sulphate reduction. Nickel can apparently participate in the subsequent reactions. If $\mathrm{Ni}$ is available, it may partly substitute for iron during authigenic sulphide formation [45]. In high-temperature assemblages $\mathrm{Ni}$ substitution is very common. A small percentage of $\mathrm{Ni}$ in pyrrhotite, for example, is not unusual in sulphide deposits $[47,48]$. In the latter case the $\mathrm{Ni}$ substitutes for $\mathrm{Fe}$ and the pyrrhotite vacancy distribution remains unchanged [49].

\section{Sources of iron and nickel}

The iron for the sulphides in the sulphate reduction reactions is usually derived from poorly crystalline $\mathrm{Fe}$ oxides such as goethite and ferrihydrite [50], which occur as coatings on silicate grains. The fact that almost all sulphide grains are attached to iron-bearing clay flakes suggests that the clay flakes may also have been a source of iron during the sulphide formation. Depending on the availability of $\mathrm{Fe}$ and $\mathrm{S}$, ferrous ions in fine-grained chlorite can serve as a source for $\mathrm{Fe}$ for the formation of sulphides [51,52]. The source for nickel is more puzzling. The sampling sites are not close to sapropels and consequently the $\mathrm{Ni}$ in the sulphides does not seem to be connected with the enrichment of $\mathrm{Ni}$ encountered in sapropels $[12,32,53]$. The $\mathrm{Ni}$ might be derived from $\mathrm{Fe}-\mathrm{Cr}$ oxides, which were found to contain varying amounts of $\mathrm{Ni}$ (Table 2). It is possible that very local factors determine the $\mathrm{Ni}$ availability.

\section{Influence of $\mathrm{Ni}$ on magnetic properties}

The presence of $\mathrm{Ni}$ in the iron sulphides will of course influence their magnetic properties. Substitution of a few percent $\mathrm{Ni}$ in pyrrhotite does not change the vacancy distribution [49], although the Curie temperature of pyrrhotite with 
just $1 \% \mathrm{Ni}$ is slightly lower than that of normal pyrrhotite [54]. If the monoclinic pyrrhotite structure is also preserved with the high $\mathrm{Ni}$ contents observed here, these sulphides are likely to be ferrimagnetic as well. In the latter case the lower number of Bohr magnetons of $\mathrm{Ni}$ in comparison with ferrous $\mathrm{Fe}$ ( 2 and $4 \mathrm{~m}_{\mathrm{B}}$, respectively) will undoubtedly have major implications for the magnetic properties.

Greigite also is a strongly ferrimagnetic mineral, but its magnetic properties are poorly understood and the influence of possible nickel substitution can only be guessed at. The chemical composition of none of the other sulphides matches that of any known mineral and their mineralogical structure could not be determined. The question of their possibly ferrimagnetic nature must be addressed by laboratory studies of synthetic equivalents.

\section{Timing of natural remanent magnetization}

Seeing as magnetic sulphides turn out to be the dominant remanence carriers, the authigenesis of the sulphides possibly resulted in non-instantaneous NRM acquisition. Such authigenesis may have obscured the position of boundaries between normal and reversed intervals in the sediment. However, in general a fast rate of sulphate reduction and formation of sulphides is restricted to a small interval in the sediment column. The reactions virtually cease as soon as sulphate from the porewater is depleted or the readily metabolizable organic matter is completely oxidized [50]. Sulphate reduction continues at a much lower rate dictated by sulphate diffusion in the sediment or the slower oxidation of the remaining organic compounds. The magnetostratigraphic results show that the polarity intervals observed in the Vrica sediment compare well with the geomagnetic polarity time scale for the time interval in question [8]. The results thus suggest that the majority of the magnetic sulphides must have formed in a relatively short period not long after sedimentation. Small-scale variations in magnetic properties and consequent differences in demagnetization behaviour of some samples may indicate that very locally magnetic sulphides can have formed over a longer period of time. This could be due to the local occurrence of less accessible organic material (e.g. within the carbonate shell of Fig. 4d).

\section{Conclusions}

The rock magnetic parameters of the PlioPleistocene open-marine marls of the Vrica section point to magnetic iron sulphide as a remanence carrier, although the blocking temperatures of NRM and IRM are too high for stoichiometric monoclinic pyrrhotite $\left(340-360^{\circ} \mathrm{C}\right)$.

Magnetic concentrates of the sediment were prepared for microprobe analysis. However, in spite of two upgrading steps abundant ironbearing clay flakes still remained in the concentrates. Attached to the clay flakes are numerous small spherical sulphide grains, most of which are smaller than $1.5 \mu \mathrm{m}$. Microprobe analysis reveals that these grains are iron-nickel sulphides with nickel contents of as much as $35 \%$ of the total metal content. Apart from pyrite many monosulphide compositions are present, and these normally comprise an intermediate stage in authigenic pyrite formation. This and other observations indicate that the sulphides are of authigenic origin.

Four major compositional groups can be distinguished: (1) pyrite with a few percent $\mathrm{Ni}$, (2) greigite-pyrrhotite compositions with usually between between 20 and 35\% Ni, (3) sulphur-deficient pentlandite-like compositions with between 0 and $32 \% \mathrm{Ni}$, and (4) even more sulphur deficient compositions with between 5 and $15 \% \mathrm{Ni}$. The compositions of group (2), (3) and (4) do not match those of any known mineral. The high $\mathrm{Ni}$ contents in particular are different from those of any natural sulphides hitherto reported. (A more detailed mineralogical characterization of the mineral phases by X-ray diffraction was not successful due to the high clay content of the magnetic concentrates, which resulted in the sulphides being below the detection limit.)

It is not possible to determine which of the sulphides is magnetic. The only phase that can be inferred to be ferrimagnetic has a composition close to that of monoclinic pyrrhotite, but with $\mathrm{Ni}$ replacing $20-35 \%$ of the Fe. The influence of the high $\mathrm{Ni}$ substitution on the properties of pyrrhotite is not known. The fact that the pentlandite-like sulphides form the largest group of 
sulphide compositions in the magnetic concentrates suggests that they are ferrimagnetic too. Further studies to characterize the mineral phases and their possible ferrimagnetic structure are in progress.

\section{Acknowledgements}

We thank the reviewers for their suggestions, and A.v.V. thanks the Vrica B crew for their enthusiasm. Microprobe facilities and $\mathrm{X}$-ray diffraction facilities were provided by the Geochemistry Department of Utrecht University. T. Bouten assisted with the operation of the microprobe, and the XRD was carried out by H.M.V.C. Govers. M.J.D. acknowledges a fellowship from the Royal Netherlands Academy of Sciences and Arts.

\section{References}

1 E. Aguirre and G. Pasini, The Plio-Pleistocene boundary, Episodes 8, 116-120, 1985.

2 G. Pasini, R. Selli, R. Tampieri, M.L. Colalongo, S. d'Onofrio, A.M. Borsetti and F. Cati, The Vrica section, in: The Neogene-Quarternary Boundary, II Symp. Bologna-Crotone, Excursion Guidebook, R. Selli, ed,, pp. 62-72, 1975.

3 R. Selli, C.A. Accorsi, M. Bandini Mazzanti, D. Bertolani Marchetti, G. Bigazzi, F.P. Bonadonna, A.M. Borsetti, F. Cati, M.-L. Colalongo, S. d'Onofrio, W. Landini, E. Menesini, R. Mezzeti, G. Pasini, G. Savelli and R. Tampieri, The Vrica section (Calabria). A potential Neogene-Quarternary boundary stratotype, G. Geol. 41, 181-204, 1977.

4 J.D. Obradovitch, C.W. Naeser, G.A. Izett, G. Pasini and G. Bigazzi, Age constraints on the proposed Plio-Pleistocene boundary stratotype at Vrica, Italy, Nature 298, 55$59,1982$.

5 J. Backman, N.J. Shackleton and L. Tauxe, Quantitative nannofossil correlation to open ocean deep-sea sections from Plio-Pleistocene boundary at Vrica, Italy, Nature 304, 156-158, 1983.

6 L. Tauxe, N.D. Opdyke, G. Pasini and C. Elmi, Age of the Plio-Pleistocene boundary in the Vrica section, southern Italy, Nature 304, 125-129, 1983.

7 F.J. Hilgen, Closing the gap in the Plio-Pleistocene boundary stratotype sequence of Crotone (southern Italy), Newslett. Stratigr. 22, 43-51, 1990.

8 J.D.A. Zijderveld, F.J. Hilgen, C.G. Langereis, P.J.J. Verhallen and W.J. Zachariasse, Integrated magnetostratigraphy and biostratigraphy of the upper Pliocene-lower Pleistocene from the Monte Singa and Crotone areas in Calabria, Italy, Earth Planet. Sci. Lett. 107, 697-714, 1991.

9 F.J. Hilgen, Sedimentary rhythms and high-resolution chronostratigraphic correlations in the Mediterranean Pliocene, Newslett. Stratigr. 17, 109-127, 1987.
10 F.J. Hilgen, Astronomical calibration of Gauss to Matuyama sapropels in the Mediterranean and implication for the Geomagnetic Polarity Time Scale, Earth Planet. Sci. Lett. 104, 226-244, 1991.

11 R.C. Thunell, Pliocene-Pleistocene climatic changes: evidence from land-based and deep-sea marine records, Mem. Soc. Geol. It. 31, 135-143, 1986.

12 C.H. Van der Weijden, Geochemical signatures preserved in sediments of the Semaforo and Vrica sections (Calabria, Italy) and their relations with variations of the sedimentary regime, Palaeogeogr., Palaeoclimatol., Palaeoecol., in press.

13 N. Combourieu-Nebout, Les premiers cycles glaciaires-interglaciaires en région Méditerranéenne d'après l'analyse palynologique de série Plio-Pleistocène de Crotone (Italie Méridionale), 161 pp., Thesis, Univ. Sciences et Techniques du Languedoc, 1987.

14 D.J. Dunlop, Hysteresis properties of magnetite and their dependence on particle size: a test of pseudo-single-domain remanence models, J. Geophys. Res. 91, 9569-9584, 1986.

15 D.A. Clark, Hysteresis properties of sized dispersed monoclinic pyrrhotite grains, Geophys. Res. Lett. 11, 173-176, 1984.

16 M.J. Dekkers, Magnetic properties of natural pyrrhotite. Part I: Behaviour of initial susceptibility and saturationmagnetization-related rock-magnetic parameters in a grain-size dependent framework, Phys. Earth Planet. Inter. 52, 376-393, 1988.

17 A.J. Van Velzen and J.D.A. Zijderveld, A method to study alterations of magnetic minerals during thermal demagnetization applied to a fine-grained marine marl (Trubi formation, Sicily), Geophys. J. Int. 110, 79-90, 1992.

18 E.J. Schwarz and D.J. Vaughan, Magnetic phase relations of pyrrhotite, J. Geomagn. Geoelectr. 24, 441-458, 1972.

19 E.J. Schwarz, Magnetic properties of pyrrhotite and their use in applied geology and geophysics, Geol. Surv. Can. Pap. 74-59, 24 pp., 1975.

20 D.J. Vaughan and J.R. Craig, Mineral Chemistry of Metal Sulfides, 493 pp., Cambridge University Press, Cambridge, 1978.

21 M.J. Dekkers, Magnetic properties of natural pyrrhotite. Part II. High- and low-temperature behaviour of $J_{\text {rs }}$ and TRM as function of grain size, Phys. Earth Planet. Inter. 57, 266-283, 1989.

22 P. Rochette, G. Fillion, J.-L. Mattéi and M.J. Dekkers, Magnetic transition at 30-34 Kelvin in pyrrhotite: insight into a widespread occurrence of this mineral in rocks, Earth Planet. Sci. Lett. 98, 319-328, 1990.

23 E.J. Schwarz, Magnetization of Precambrian sulphide deposits and wall rocks from the Noranda district, Canada, Geophysics 31, 797-802, 1966.

24 G.F. Thomson, The anomalous demagnetization of pyrrhotite, Geophys. J. Int. 103, 425-430, 1990.

25 I. Snowball, Magnetic hysteresis properties of greigite $\left(\mathrm{Fe}_{3} \mathrm{~S}_{4}\right)$ and a new occurrence in Holocene sediments from Swedish Lappland, Phys. Earth Planet. Inter. 68, 32-40, 1991.

$26 \mathrm{~V}$. Hoffmann, Greigite $\left(\mathrm{Fe}_{3} \mathrm{~S}_{4}\right)$ : magnetic properties and 
first domain observations, Phys. Earth Planet. Inter. 70, 288-301, 1992.

27 J.C. Diaz Ricci and J.L. Kirschvink, Magnetic domain state and coercivity predictions for biogenic greigite $\left(\mathrm{Fe}_{3} \mathrm{~S}_{4}\right)$ : a comparison of theory with magnetosome observations, J. Geophys. Res. 97, 17,309-17,315, 1992.

28 M. Krs, M. Krsová, P. Pruner, A. Zeman, F. Novák and J. Jansa, A petromagnetic study of Miocene rocks bearing micro-organic material and the magnetic mineral greigite (Sokolov and Cheb basins, Czechoslovakia), Phys. Earth Planet. Inter. 63, 98-112, 1990.

29 F.D. Stacey and S.K. Banerjee, The Physical Principles of Rock Magnetism, 195 pp., Elsevier, Amsterdam, 1974.

30 M.A. Huerta-Diaz and J.W. Morse, Pyritization of trace metals in anoxic marine sediments, Geochim. Cosmochim. Acta 56, 2681-2702, 1992.

31 M. Krs, F. Novák, M. Krsová, P. Pruner, L. Kouklíková and J. Jansa, Magnetic properties and metastability of greigite-smythite mineralization in brown-coal basins of the Krusné hory Piedmont, Bohemia, Phys. Earth Planet. Inter. 70, 273-287, 1992.

32 P.A. Pruysers, G.J. de Lange and J.J. Middelburg, Geochemistry of eastern Mediterranean sediments: Primary sediment composition and diagenetic alterations, Mar. Geol. 100, 137-154, 1991.

$33 \mathrm{H}$. Shimazaki, Thermochemical stability of bravoite, Econ. Geol. 66, 1080-1082, 1971.

34 O. Jover, P. Rochette, J.P. Lorand, M. Maeder and J.L. Bouchez, Magnetic mineralogy of some granites from the French Massif Central: origin of their low-field susceptibility, Phys. Earth Planet. Inter. 55, 79-92, 1989.

35 L.A. Taylor, Smythite, $\mathrm{Fe}_{3+\mathrm{x}} \mathrm{S}_{4}$, and associated minerals from the Silverfields Mine, Cobalt, Ontario, Am. Mineral. $55,1650-1658,1970$.

36 H. Nakazawa, T. Osaka and K. Sakaguchi, A new cubic iron sulphide prepared by vacuum deposition, Nature Phys. Sci. 242, 13-14, 1973.

37 D.J. Vaughan, Nickelian mackinawite from Vlakfontein, Transvaal, Am. Mineral. 54, 1190-1193, 1969.

38 A.H. Clark, Preliminary observations on chromian mackinawite and associated native iron, Mina do Abessedo, Vinhais, Portugal, Jahrb. Mineral Monatsh. 6, 282-288, 1969.

39 J.A. Morice, L.V.C. Rees and D.T. Rickard, Mössbauer studies of iron sulphides, J. Inorg. Nucl. Chem. 31, 3797$3802,1969$.

40 D.J. Vaughan and M.S. Ridout, Mössbauer studies of some sulphide minerals, J. Inorg. Nucl. Chem. 33, 741-746, 1971.
41 R.A. Berner, Authigenic mineral formation resulting from organic matter decomposition in modern sediments, Fortschr. Mineral. 59, 117-135, 1981.

42 R.A. Berner, Sedimentary pyrite formation: An update, Geochim. Cosmochim. Acta 48, 605-615, 1984.

43 J.-R. Mossmann, A.C. Aplin, C.D. Curtis and M.L. Coleman, Geochemistry of inorganic and organic sulphur in organic-rich sediments from the Peru Margin, Geochim. Cosmochim. Acta 55, 3581-3595, 1991.

44 R.E. Sweeny and I.R. Kaplan, Pyrite framboid formation: laboratory synthesis and marine sediments, Econ. Geol $68,618-634,1973$.

45 G.W. Luther, III, A.L. Meyerson, J.J. Krajewski and R. Hires, Metal sulfides in estuarine sediments, J. Sediment. Petrol. 50, 1117-1120, 1980.

46 I. Snowball and R. Thompson, A stable chemical remanence in Holocene sediments, J. Geophys. Res. 95, 44714479, 1990.

47 N.J. Page, Pentlandite and pyrrhotite from the Stillwater complex, Montana: iron-nickel ratios as a function of associated minerals, Econ. Geol. 67, 814-820, 1972.

48 K.C. Misra and M.E. Fleet, The chemical compositions of synthetic and natural pentlandite assemblages, Econ. Geol. $68,518-539,1973$.

49 N.N. Shishkin, G.A. Mitenkov, V.A. Mikhaylova, N.S. Rudashevsiy and A.F. Sidorov, Nickel, cobalt and copper in pyrrhotite from massive ores of the Talnakh ore cluster, Geochem. Int. 11, 76-84, 1974 (Transl. from Geokhimiya 1, 95-104, 1974).

50 M.B. Goldhaber and I.R. Kaplan, The sulfur cycle, in: The Sea, Vol. 5, Marine Chemistry, E.D. Goldberg, ed., pp. 569-655, Wiley, 1974.

51 P.G. Manning, J.D.H. Williams, M.N. Charlton, L.A. Ash and T. Birchall, Mössbauer spectral studies of the diagenesis of iron in a sulphide-rich sediment core, Nature 280 , 134-136, 1979.

52 R.J. Suttill, P. Turner and D.J. Vaughan, The geochemistry of iron in Recent tidal-flat sediments of the Wash area, England: a mineralogical, Mössbauer, and magnetic study, Geochim. Cosmochim. Acta 46, 205-217, 1982.

53 S.E. Calvert, Geochemistry of Pleistocene sapropels and associated sediments from the Eastern Mediterranean, Oceanol. Acta 6, 255-267, 1983.

54 D.J. Vaughan, E.J. Schwarz and D.R. Owens, Pyrrhotites from the Strathcona Mine, Sudbury, Canada: a thermomagnetic and mineralogical study, Econ. Geol. 66, 1131$1144,1971$. 